Contemporary Herpetology

ISSN 1094-2246

2000 Number 3

19 September 2000

\title{
PROTEINS OF PAROTOID GLAND SECRETIONS FROM TOADS OF THE GENUS BUFO
}

David Perry (perryd@wmin.ac.uk)

School of Biosciences, University of Westminster, 115 New Cavendish Street, London W1M 8JS

Abstract - Freeze-dried parotoid gland secretions from toads of the genus Bufo contained large proportions of protein (25-35\% by weight). SDSPAGE suggested that secretions from several species of Bufo contained mixtures of proteins in the relative molecular mass range of approximately 12 - $200 \mathrm{kDa}$, which exhibited markedly different banding patterns from species to species. These proteins were presumably not discovered before because the previous extraction procedures used with these secretions were designed to examine low molecular mass compounds and would denature the proteins. SDS-PAGE of secretions from $B$. mauritanicus and $B$. calamita are shown here. The N-terminal amino acid sequence of one of the bands (approx. 58 $\mathrm{kDa}$ ) of $B$. mauritanicus was found to be LPIPAFPGLDHGF and of a $B$. calamita band $(30.5 \mathrm{kDa})$ was VQVFGLQKEA. No significant similarities to these two sequences and to three separate but partial $\mathrm{N}$-terminal sequences obtained from these species were found in genetic databases.

The granular ('venom') gland secretions from amphibians are known to be rich in low molecular weight constituents of varied molecular types such as steroids, amines and peptides. Much of the interest in these secretions is a consequence of their bioactivities, which may have partly evolved as one mode of anti-predator defense. However, as pointed out by Barthalmus (1994) in reviewing biological roles of amphibian skin secretions (using the wellstudied Xenopus laevis as a model), there are few pointers to any role other than defense for this complex biochemical cocktail; more careful study may therefore prove biologically enlightening. 
Toads of the genus Bufo have compact parotoid glands situated on the neck, sides of the head or shoulder regions which accumulate a milky secretion. A variety of compounds in such secretions from different Bufo species have been separated by two-dimensional paper chromatography with multiple staining techniques and the patterns used in evolutionary studies (Low, 1972). No antimicrobial peptides such as discovered in $X$. laevis skin (reviewed by Bevins and Zasloff, 1990; relative molecular mass up to some $3 \mathrm{kDa}$ ) have been reported yet in Bufo. While examining secretions from two Bufo species for the presence of such low relative molecular mass peptides by SDS-PAGE, it was observed in this laboratory that there were a number of proteins present of much higher relative molecular mass than might have been expected (reported by Clarke, 1997). This report reveals that a complex array of proteins is present in such secretions and provides the results of some preliminary $\mathrm{N}$-terminal amino acid analysis of proteins from $B$. mauritanicus and B. calamita.

\section{MATERIALS AND METHODS}

Buffer components and SDS were obtained from Sigma (Poole, Dorset, UK). Acrylamide and PVDF membrane were obtained from Bio-Rad (Hemel Hempstead, Herts, UK). Bufo mauritanicus (originally from Morocco) and $B$. calamita (originally from the United Kingdom) were kindly loaned from the collection of M. Linley. Using gentle pressure, the parotoid secretions were expressed into ammonium bicarbonate solution ( 1.0 or $2.0 \mathrm{~mL}, 0.05 \mathrm{M}$ ) and agitated gently to produce a milky solution. This method of obtaining the secretions is like that described by Bolliger and Meyer (1957), except that they expressed the secretions onto a glass plate and allowed them to harden before solvent extraction. Subsequent freeze-drying yielded white-to-cream flocculent solids. The freeze-dried secretions were dissolved in $0.1 \% \mathrm{NaCl}$ and assayed by the Bradford (1976) or biuret methods using gamma-globulin as standard.

SDS Polyacrylamide gel electrophoresis was carried out by the method of Laemmli (1970) using mini gels (12\% T; $3.3 \%$ C). Sample loadings were typically 5 microL of a $20 \mathrm{mg} / \mathrm{mL}$ solution in sample buffer. When required, protein bands were visualized by Coomassie Blue R-250 staining. Molecular weight standards were from Bio-Rad.

Proteins were blotted onto PVDF membrane using a semi-dry method after preparation according to Matsudaira (1987). Gels were soaked in blotting buffer (10 mM CAPS in 10\% methanol) for 5 minutes. The membrane was 
wetted with methanol and then transferred into blotting buffer. The gel/PVDF sandwich was assembled between filter paper (2 pieces each side; Whatman no. 3) soaked in blotting buffer and transfer carried out for $1.5 \mathrm{~h}\left(3 \mathrm{~mA} / \mathrm{cm}^{2}\right)$. The blot was rinsed with distilled water, followed by methanol, and then stained with Coomassie Blue R-250 (0.1\% in 10\% acetic acid $/ 50 \%$ methanol) until the bands appeared. Destaining was with $10 \%$ acetic acid $/ 50 \%$ methanol followed by rinsing with distilled water.

$\mathrm{N}$-Terminal sequencing of selected bands was carried out commercially. Database searching for sequence similarities was performed using TBLASTN (Altschul et al., 1990) and FASTA (Pearson and Lipman, 1988).

\section{RESULTS AND DISCUSSION}

The parotoid gland secretions harden if left to stand and in the past have often been used in that state for extraction of low molecular mass components. By expressing the extracts immediately into a volatile buffer as described here in Methods, the proteins are rendered amenable for study. The extraction procedures used in the past were aimed at low molecular mass components and would often have denatured the protein components. However, determination of protein concentration in solutions of freeze-dried secretions by both the Bradford (1976) and biuret methods showed that the gland secretions contain some $25-35 \%$ protein by dry weight.

Initial experiments with 6 species of Bufo (up to 3 individuals from each species) suggested that the protein patterns obtained after SDS-PAGE and Coomassie Blue staining were markedly different from species to species. Figure 1 shows the results of SDS-PAGE after Coomassie Blue staining of secretions from individual specimens of $B$. mauritanicus and $B$. calamita. Despite the crude nature of these secretions, the gel resolution was satisfactory, although improvements might be expected by prior molecular weight fractionation using membrane filters. The protein patterns from these two species are clearly different and cover a wide range of molecular size. Such gel patterns may prove useful in taxonomic or evolutionary studies. Parotoid secretions could be obtained easily in the field and prove useful in species identification, particularly where anatomical criteria are ambiguous.

Unstained gels similar to those shown were blotted onto PVDF membrane, the protein bands visualized with Coomassie Blue and submitted for $\mathrm{N}$ terminal sequencing. Due to the complexity of the protein patterns the choice of bands was made on their ease of excision as a single band and their 
preliminary sequencing behaviour. Of three bands from a $B$. mauritanicus blot (marked as A, B and C in Figure 1), two gave only partial or ambiguous sequences and one gave a complete run of twelve residues as shown in Table 1. The marked similarities in these 3 sequences suggests posttranslational processing or a family of related proteins. Proteolytic processing has been deduced to occur in the production of frog skin peptides (see Kreil, 1996). Two different $\mathrm{N}$-terminal sequences were obtained from the somewhat diffuse major band of the $B$. calamita gel and are also given in Table 1 . It is not uncommon for such broad bands to be found to consist of more than one protein. One component gave a complete run of 9 residues from the $\mathrm{N}$ terminus. The other component is probably $\mathrm{N}$-blocked since the first residue could not be identified and there was also ambiguity at the third residue. No significant similarities to known sequences were found for any of these small Bufo sequences by searching protein and nucleic acid databases.

The presence of these arrays of proteins in Bufo parotoid gland secretions suggests a more complex role for these secretions than simply anti-predator defense. The peptides found in various species of toads and frogs which possess antimicrobial activities are of a much smaller molecular size range than encompassed by SDS-PAGE as used here. For instance, the magainins found in skin secretions of Xenopus are typically of 21-26 amino acid residues in length (reviewed by Bevins and Zasloff, 1990), resulting in molecular masses of 2.300-2.8 $\mathrm{kDa}$. A peptide of a somewhat larger size than this $(6.7$ $\mathrm{kDa}$ ) found in Bombina variegata pachypus was suggested to possess antimicrobial activity (Barberio et al., 1987). Peptides of these sizes are not retained by the sieving effects of polyacrylamide gels as used here and run to the bottom (or run off the bottom) of the gel. The experiments of Barberio et al. (1987) with Bombina also used lyophilized skin secretions, but obtained from the skin of sacrificed animals. Interestingly, proteins in the larger size range described in this paper for Bufo were observed also in SDS-PAGE of the Bombina secretions, but they appear to be less abundant than the low molecular weight species - the reverse of what is found here in Bufo parotoid gland secretions.

It seems unlikely that so many large proteins as seen here in the Bufo would be directly involved in antimicrobial defense (as are the magainins for example). There are possibilities for indirect means of involvement, however, since enzymes have been suggested to be involved in the conversion of bufotoxins to free bufogenins (cardioactive steroids) by ester hydrolysis in Bufo parotoid gland secretions (Meyer and Linde, 1971) and have been deduced to be involved in the 'processing' of high molecular mass protein 
precursors into the smaller active magainin peptides as mentioned earlier. A peptidase activity was detected in the skin secretion of Bombina variegata (Molzer and Michl, 1967).

Further work is in progress to assess the similarities and differences in banding patterns from different individuals of the same species and from a greater range of Bufo species. As pointed out by Clarke (Clarke, 1997), the use of Bufo for this sort of biochemical investigation is convenient compared with sampling from other types of amphibians. The secretion 'milking' can be repeated frequently without any harm to the animal.

\section{ACKNOWLEDGMENTS}

I am grateful to Sapna Patel and Ben Rees for technical assistance and to Dr Barry Clarke, Curator of Amphibians, Natural History Museum, London, for introducing me to research in Bufo gland secretions.

\section{REFERENCES}

ALTSCHUL, S. F., W. GISH, W. MILLER, E.W. MYERS AND D.J. LIPMAN. 1990. Basic local alignment search tool. Journal of Molecular Biology 215: 403-410.

BARBERIO, C., D. GIOVANNI. AND G. MASTROMEI.

1987. A low molecular weight protein with antimicrobial activity in the cutaneous 'venom' of the yellow-bellied toad Bombina variegata pachypus. Toxicon 25: 899-909.

BARTHALMUS, G. T.

1994. Biological roles of amphibian skin secretions. Pp. 382-

410 in Amphibian Biology. H. Heatwole, G. T. Barthalmus, and A. Y. Heatwole (eds.). Chipping Norton, NSW Australia: Surrey Beatty \& Sons Pty Limited.

BEVINS, C. L. AND M. ZASLOFF. 1990. Peptides from frog skin. Annual Review of Biochemistry 59: 395414.

BOLLIGER, V. R. AND K. MEYER. 
1957. Isolierung und Identifizierung der Steroide des Giftsekretes der Berberkrote (Pantherkrote) Bufo mauritanicus L. Helvetica Chimica Acta 50: 1659-1670.

BRADFORD, M. M.

1976. A rapid and sensitive method for the quantification of microgramme quantities of protein utilizing the principle of protein-dye binding. Analytical Biochemistry 72: 248-254.

CLARKE, B. T.

1997. The natural history of amphibian skin secretions, their normal functioning and potential medical applications. Biological Reviews 72: 365-379.

KREIL, G.

1996. Skin secretions of Xenopus laevis. Pp. 263-277 in The Biology of Xenopus. Symposia of the Zoological Society of London (68). R. C. Tinsley and H. R. Kobel (eds.).

LAEMMLI, U.

1970. Cleavage of structural proteins during the assembly of the head of bacteriophage T4. Nature 227: 680-685.

LOW, B. S.

1972. Evidence from parotoid-gland secretions. Pp. 244-264

in Evolution in the Genus Bufo. W. F. Blair (ed.). Austin \& London: University of Texas Press.

MATSUDAIRA, P.

1987. Sequence from picomole quantities of proteins electroblotted onto polyvinylidene difluoride membranes. Journal of Biological Chemistry 262: 10035-10038.

MEYER, K. AND H. LINDE.

1971. Collection of toad venoms and chemistry of the toad venom steroids. Pp. 521-556 in Venomous Animals and Their Venoms. Volume II. W. Bücherl and E.F. Buckley (eds.). Academic Press, New York.

MOLZER, H. AND M. MICHL.

1967. The LNA-hydrolysing enzyme in the toxin of Bombina variegata.

Toxicon 5: 105. 
PEARSON, W. R. AND D.J. LIPMAN.

1988. Improved tools for biological sequence comparison. Proceedings of the National Academy of Sciences USA 85: 2444-2448. 